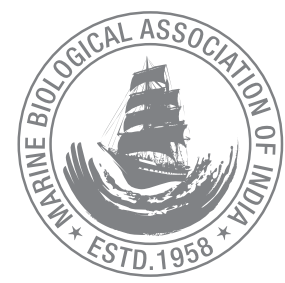

\title{
Coastal rural indebtedness and impact of microfinance in marine fisheries sector of Tamil Nadu
}

\author{
V.P. Vipinkumar*, B. Johnson, P.S. Swathilekshmi and C. Ramachandran \\ Socio Economic Evaluation \& Technology Transfer Division, Central Marine Fisheries Research Institute, Kochi \\ *Correspondence e-mail: vipincmfri@gmail.com
}

Received: 15 Dec 2012, Accepted: 20 May 2013, Published: 15 Jun 2013

Original Article

\begin{abstract}
In this paper an attempt is made to assess the extent of indebtedness among marine fisherfolk in mechanized, motorized and traditional fisheries sectors and to assess the impact of Microfinance Institutions (MFI) and Self Help Groups (SHG) on coastal indebtedness in Tamil Nadu. The study was carried out in three coastal districts of the state. Situational analysis was done through PLA in the selected locations and the sample respondents were selected from mechanized, motorized, traditional, secondary and tertiary sectors. Data were collected through personal interview from members of 12 selected MFIs and non members in these sectors, comprising a total of 600 respondents. The results showed that the level of indebtedness of members of MFls was less compared to the non members. In certain cases, even though the indebtedness was more, the level of repayment was found to be significantly high in MFls. There is an extreme necessity of strengthening the MFI ventures in the traditional fisheries sector in the state. A comparative assessment of the sources of credit also was undertaken to draw valid conclusions. It was found that the MFIs ranked better in most of the attributes in the perception of stakeholders compared to banks and non-institutional credit sources.
\end{abstract}

Keywords: Microfinance, indebtedness, credit, Self Help Groups.

\section{Introduction}

The extent of coastal rural indebtedness in the marine fisheries sector is quite observable throughout the Indian coastal belts. The Micro Finance Institutions/Self Help Groups mobilised in marine fisheries sector do play a vital role in reducing the vicious circle of indebtedness among marine fisherfolk. An exact assessment on the indebtedness level has not so far been attempted among marine fisherfolk. The extent and quantum of indebtedness at a reasonable level of interest sourced out from the organized sector is an indicator of development since availability of finances boost up the economic activity and capital formation in a region. The extent of indebtedness and the average outstanding debt per indebted households are comparatively less among fishermen as per the figures of institutional sources, but the affairs of the fisherfolk are really grim as they are virtually gripped in the hands of noninstitutional agencies, namely the money lenders and traders for which legitimate data sources do not exist. Fisherfolk are attracted to the non-institutional agencies on account of simple procedures and timeliness in availing finance and for operational expenses which ultimately make them suffer from debt trap and vicious circle of indebtedness. As cheap credit is always essential for development of Indian marine fisheries sector, microfinance institutions play a distinct role 
in this regard to offer low cost credit and thereby save the fisherfolk from permanent debt trap. For mobilized group ventures, several names exist like Micro Finance Institution (MFI), Self Help Group (SHG), Farmer Entrepreneurial Group (FEG), Bharat Kisan Centres (BKC), Swayam Sahayak Sangh (SSS), Ayalkoottam (AK) etc. which perform an appropriate micro-enterprise and microfinance is an essential component ensuring its sustainability. Whatever may be the connotation, the essence is a mobilized group venture with a productive economic activity initiated by thrift deposits and sustained by an appropriate micro-enterprise either independently or by the intervention of an external agency where microfinance is the basis.

Mammoo (2004) in a study on income, indebtedness and savings among fisherfolk of Udayapur and Gopalpur of Odisha under BOBP Programme reported that fishing communities know two distinct credit sources: the traditional/ informal and the institutional/formal. Traditional sources include moneylenders, middlemen, fish traders, boat owners, shopkeepers and pawn brokers. Institutional sources are mainly banks and cooperatives. Yunus (1999), the pioneer of microfinance projects in Bangladesh stated that microfinance system enabled thousands of people by offering poor people loans, some fear it could lead to over-indebtedness, but microfinance has benefited the wider economy. A few studies on the impact of microfinance organizations on rural indebtedness in fisheries sector were conducted by Fisheries Co-management Case Study from the Gambia (Njie and Mikkola, 2001). Vipinkumar (2007) reported on dynamics of twelve women's Self Help Groups in Marine fisheries sector of Malabar area of Kerala and developed a strategy for mobilisation of an effective Self Help Group. Sathiadhas (2009) conducted a couple of micro level socio economic studies on indebtedness in selected fishing villages in different maritime states in India. Jayaraman (2005) undertook the performance analysis of fisherwomen Self Help Groups in Tamil Nadu and reported that, women SHGs played a substantial role in alleviating poverty and indebtedness in fisheries sector. NSSO, (2003), Ministry of Finance (2007) and CED (2008) brought out the reports of indebtedness level in the Indian agricultural sector. Kudumbashree (2010) of Kerala state reported that it had spent Rs 121.88 crores for microfinance enterprises for women empowerment. In this context, the micro finance institutions /Self Help Groups of fisherfolk do have a pivotal role in reducing the indebtedness in the marine fisheries sector. In Tamil Nadu, there are 1, 92,697 marine fishermen households with a total population of $8,02,912$ (CMFRI, 2010) and the maximum number of families are in Ramanathapuram district $(41,048)$. Women form $48 \%$ of the population with 939 females per 1000 males. There are about 1, 27,245 households below poverty line.
The major objectives of the study were to assess the extent of rural indebtedness and the role of various agencies in providing credit and repayment behaviour in marine fisheries sector in Tamil Nadu, to study the impact of selected Microfinance Institutions/Self Help Groups on rural indebtedness, supply of credit and empowerment and to study the comparative appraisal of perception of fisherfolk on MFIs, Institutional and Non institutional credit sources in terms of selected attributes.

\section{Material and methods}

For primary data collection, Ramanathapuram, Nagapattinam and Tuticorin districts were selected, since the coastal length, number of fishing village and fishing activities are more compared to other coastal districts in Tamil Nadu. Among the 184 villages in Ramanathapuram district, four villages namely Mandapam, Pamban, Victoria Nagar and Ervadi, were selected for fishing activities dominated by mechanized boats. Similarly three villages namely Nambuthalai, Vedalai, Susaiyaparpattinam were selected for fishing activities dominated by motorized sector and two villages namely Olaikuda, and Thirupalaikudi north were selected for fishing activities dominated traditional boats (catamaran). In comparison to other fishing villages, the above-mentioned villages were selected since the numbers of mechanized, motorized and traditional boats (catamaran) were more in the respective villages. Among the 56 villages in Nagapattinam district, two villages namely Nagoorupattinachery and Arcottuthurai were selected for fishing activities dominated by mechanized boats. Similarly three villages namely Tharangambadi, Chandirapady and Vanagiri were selected for fishing activities dominated by motorized and two villages namely Poompuhar and Arcottuthurai were selected for fishing activities dominated traditional boats (catamaran). Similarly in Tuticorin district also, 3 locations such as Tharvaikulam, Tuticorin and Punnakkayal areas have been identified. From the above mentioned villages, the respondents for secondary and tertiary sector were selected. Proportionate random sampling was employed in selecting respondents from mechanized, motorized and traditional fisherfolk (primary sector), secondary sector and tertiary sector respectively from the selected villages. The secondary sector respondents are indirectly related fishing and their livelihood depends on fish and fish related activities and this category includes auctioneers at landing centres, traders, whole salers / retailers, sorters, peeling shed owners / workers, supplier of ice / diesel, people involved in curing and drying, loading and unloading workers etc. The tertiary sector respondents don't have direct connection with fish but they earn their livelihood indirectly on fish related activities and this category includes petty shop owners of landing centres / harbours / fish markets, suppliers of fish / auxiliary items, worker of net factory / boat yards etc. 
The map showing the locale of the study in Tamil Nadu is presented in figure 1.

Data were also collected from members of MFIs identified in these locations. Hence, the total sample covered the respondents of four MFls selected from each of the three districts comprising a total of $12 \mathrm{MFIs}$. Any mobilized group venture with a productive economic activity initiated by thrift deposits and sustained by an appropriate micro-enterprise

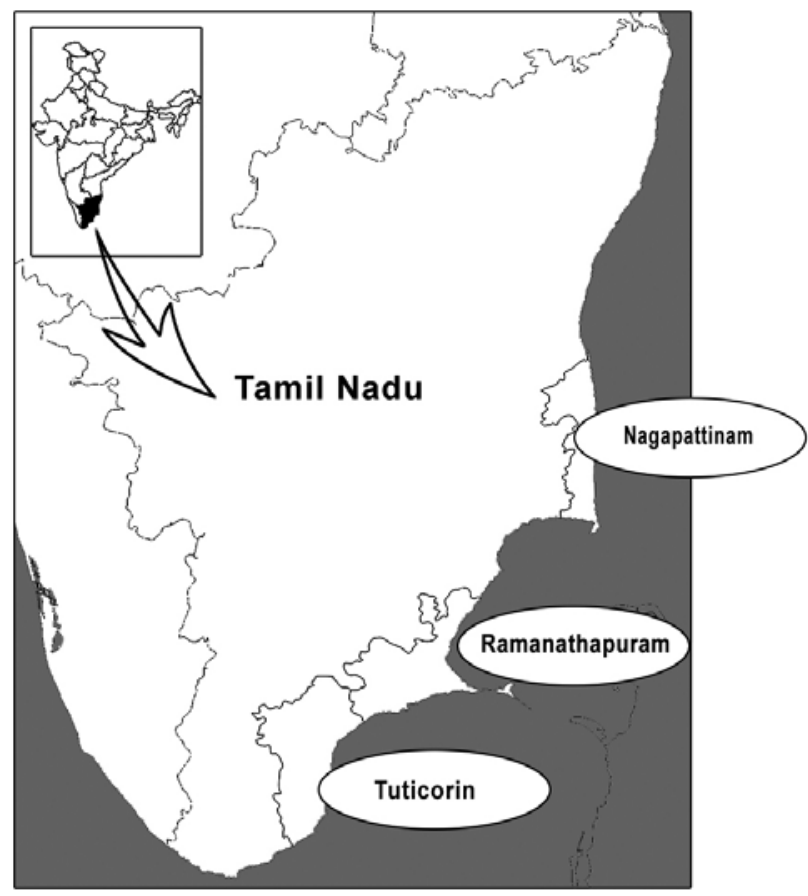

Fig.1 Map showing the study area in Tamil Nadu

either independently or by the intervention of an external agency is considered an MFI for the study. This included SHGs also which finished the gestation period of 36 months with an economic activity initiated through thrift deposits and sustained by an appropriate micro-enterprise promoted by micro-finance either independently or by the intervention of an external agency like NGOs, private micro financial firms, banks etc. In total, the data were collected from the selected 600 respondents consisting of 180 members of MFIs and 420 nonmembers in Tamil Nadu state. Situational analysis was done through PLA in the selected potential maritime locations in the above mentioned zones and the marine fisherfolk from the various strata such as mechanized, motorized and traditional sectors were taken as representative samples. Study was made through personal interview of the fisherfolk to assess the extent of coastal rural indebtedness, supply of credit and empowerment and other parameters with a pretested and standardized data collecting protocol. Success cases of MFIs on entrepreneurial capacity building were documented which significantly played the role in the debt redemption and poverty alleviation.

Similarly to study the comparative appraisal of perception of fisherfolk on MFIs, Institutional and Non institutional credit sources in terms of selected attributes, respondents were asked to assign ranks to each of the attributes to make comparison. The data obtained from the respondents were systematically tabulated. Garrett's Ranking Technique (Garret and Woodworth, 1969) was used to identify and rank the attributes on the functioning of MFIs. This technique provides the change of orders into numerical scores and the prime advantage of this technique over simple frequency distribution is that the reasons and factors are arranged based on their importance from the point of view of respondents. The per cent position of each rank was converted into scores referring to the Table given by Garret's formula for converting ranks into percent as given below:

Percent position $=100^{*}\left(\mathrm{R}_{\mathrm{ij}}-0.5\right) / \mathrm{N}_{\mathrm{j}}$

Where,

$R_{i j}=$ Rank given for ith factor by jth individual $\mathrm{N}_{\mathrm{j}}=$ Number of factors ranked by jth individual

For each factor, the scores of individual respondents were added together and divided by the total number of the respondents for whom scores were added. The mean scores for all the factors were arranged in descending order, ranks were given and the most important factors or reasons were identified. Thereby the comparative appraisal of MFIs, Institutional and Non Institutional credit agencies was made.

\section{Results and discussion}

In the impact assessment study on indebtedness as the personal and socio-psychological characteristics of the respondents like age particulars and educational status play a significant role as independent variables, a brief description of those basic parameters are given.

\section{Age particulars}

The age distribution of the respondent households is furnished in Table 1. The age of the respondents were categorized into sub groups. Fishing was mostly done by fisherfolk in the age group of 20-50 which constitutes about 83.50 per cent of the respondents. The distribution also indicated the representation of age group 20-30 constituting to 21 per cent. Majority (34.5 $\%$ ) of the fisherfolk are in the age category of 30-40 years. The fisherfolk with age more than 50 were found to be 16.5 
per cent and were represented least. It was important to note that fishing appears as a viable option for livelihood among the age group of less than 40 years in Tamil Nadu.

\section{Educational status}

The educational status includes the level of education as indicated by primary, middle, high school and above. The primary level indicated schooling till fifth grade, middle level indicated by schooling till eighth grade, high school schooling till tenth grade and above denoted by secondary and vocational education, collegiate and professional education. The results are presented in Table 2 . The results indicate that a substantial difference in the level of indebtedness across the non-member and member fisherfolk of MFIs on account of their higher repayment capacity, less risk involvement and easiness in availing credit.

Distribution of respondents based on repayment of loan The repayment of loan by non members and MFI members was studied and the results are presented in Table 4 and 5. The study found that 26 per cent of SHG/ MFI members were able to repay 81-100 per cent of the loan which they borrowed. It is interesting to note that 43.5 per cent of respondents as individual were not able to repay their loan which they borrowed, whereas under MFIs only 19 per cent

Table 1. Distribution of respondents based on age

\begin{tabular}{|c|c|c|c|c|c|c|c|c|c|c|c|c|}
\hline \multirow[t]{2}{*}{ Category } & \multicolumn{2}{|c|}{ Mechanized $(n=120)$} & \multicolumn{2}{|c|}{ Motorized $(n=120)$} & \multicolumn{2}{|c|}{ Traditional $(n=120)$} & \multicolumn{2}{|c|}{ Secondary $(n=120)$} & \multicolumn{2}{|c|}{ Tertiary $(n=120)$} & \multicolumn{2}{|c|}{ Total $(n=600)$} \\
\hline & No & $\%$ & No & $\%$ & No & $\%$ & No & $\%$ & No & $\%$ & No & $\%$ \\
\hline $20-30$ & 24 & 20.0 & 27 & 22.5 & 15 & 12.5 & 30 & 25.0 & 30 & 25.0 & 126 & 21 \\
\hline $30-40$ & 54 & 45.0 & 27 & 22.5 & 39 & 32.5 & 48 & 40.0 & 39 & 32.5 & 207 & 34.5 \\
\hline $40-50$ & 33 & 27.5 & 33 & 27.5 & 42 & 35.0 & 27 & 22.5 & 33 & 27.5 & 168 & 28 \\
\hline $50-60$ & 09 & 7.5 & 24 & 20.0 & 18 & 15.0 & 09 & 7.5 & 18 & 15.0 & 78 & 13 \\
\hline $60-70$ & - & - & 09 & 7.5 & 06 & 5.0 & 06 & 5.0 & - & - & 21 & 3.5 \\
\hline
\end{tabular}

Table 2. Distribution of respondents based on educational status

\begin{tabular}{|c|c|c|c|c|c|c|c|c|c|c|c|c|}
\hline \multirow[t]{2}{*}{ Category } & \multicolumn{2}{|c|}{ Mechanized $(n=120)$} & \multicolumn{2}{|c|}{ Motorized $(n=120)$} & \multicolumn{2}{|c|}{ Traditional $(n=120)$} & \multicolumn{2}{|c|}{ Secondary $(n=120)$} & \multicolumn{2}{|c|}{ Tertiary $(n=120)$} & \multicolumn{2}{|c|}{ Total $(N=(n=600)$} \\
\hline & No & $\%$ & No & $\%$ & No & $\%$ & No & $\%$ & No & $\%$ & No & $\%$ \\
\hline Illiterate & 36 & 30.0 & 45 & 37.5 & 30 & 25.0 & 39 & 32.5 & 36 & 30.0 & 186 & 31 \\
\hline Primary & 33 & 27.5 & 57 & 47.5 & 54 & 45.0 & 54 & 45.0 & 33 & 27.5 & 231 & 38.5 \\
\hline Middle School & 42 & 35.0 & 09 & 7.5 & 21 & 17.5 & 15 & 12.5 & 27 & 22.5 & 114 & 19 \\
\hline High School \& Above & 09 & 7.5 & 09 & 7.5 & 15 & 12.5 & 12 & 10.0 & 24 & 20.0 & 69 & 11.5 \\
\hline
\end{tabular}

among the literates 38.5 per cent had primary education, 19 percent had middle education and 11.5 per cent had high school and above level of education. It was found that 31 per cent of respondents were illiterates.

\section{Level of indebtedness of MFI members and nonmembers}

Out of the 420 non MFI members selected, 366 were indebted and out of 180 members of 12 MFls selected, 155 were indebted and the level of respondents was 521 out of $600 \mathrm{i}, \mathrm{e}$ $87 \%$ and the per household indebtedness was found to be 1.03 lakhs. The level of indebtedness observed in the present study is also in agreement with the findings of the report on assessment of literacy, income and health status of fishers in India (CMFRI, 2012). The level of indebtedness of MFI members and non members from the representative samples drawn from three districts is presented in Table 3. There was
Table 3. Level of indebtedness across the sectors

\begin{tabular}{lll}
\hline \multirow{2}{*}{ Sector } & \multicolumn{2}{l}{ Indebtedness in Rupees lakhs } \\
\cline { 2 - 3 } & Non members & MFI members \\
\hline Mechanised & 1.09 & 0.85 \\
\hline Motorised & 0.89 & 0.54 \\
\hline Traditional & 0.71 & 0.50 \\
\hline Secondary sector & 1.84 & 1.50 \\
\hline Tertiary sector & 1.39 & 1.00 \\
\hline
\end{tabular}

were not able to repay. Microfinance institution/self help group significantly reduced the dependence of fisherfolk on private moneylenders and considerably reduced the indebtedness level and increased their repayment capacity. It assisted the fisherfolk in meeting their expenditure on purchasing of nets, repairing boats and for buying other accessories to a commendable extent. 


\section{Distribution of respondents based on source of indebtedness}

The distribution of respondents based on source of indebtedness was studied and presented in Table 6 .

Panikkar (1980) found that 87 per cent of fishermen are indebted to money lender followed by boat owners (6.9 $\%$ ). The present study found that 30.86 per cent of marine fisherfolk are indebted to banks, followed by 30.26 per cent indebted to private money lenders. Apart from these, a good proportion of them $(23.45 \%)$ have borrowed money from their respective microfinance institution/ self help group. Though the majority of the respondents are indebted to banks, MFIs were also found to possess a significant position in providing cheap credit to a considerable extent in Tamil Nadu, eventhough the magnitude of the loan provided through MFIs was less compared to banks. Throughout the coastal belts of India, the same feature was noticed in the study of Vipinkumar et al (2013) as banks are the major source of loan. The fisherfolk are bound to sell their catch to fish traders from whom they borrowed the money. Instead of taking interest for the borrowed money, fish traders buy at two to ten rupees less than the actual price for each kilogram of their

Table 4. Distribution of respondents based on repayment of loan (non MFI members)

\begin{tabular}{|c|c|c|c|c|c|c|c|c|c|c|c|c|c|}
\hline \multirow[t]{2}{*}{ S.No } & \multirow{2}{*}{$\begin{array}{l}\text { Category } \\
\text { (in \%) }\end{array}$} & \multicolumn{2}{|c|}{ Mechanized $(n=78)$} & \multicolumn{2}{|c|}{ Motorized $(n=82)$} & \multicolumn{2}{|c|}{ Traditional $(n=65)$} & \multicolumn{2}{|c|}{ Secondary $(n=70)$} & \multicolumn{2}{|c|}{ Tertiary $(n=72)$} & \multicolumn{2}{|c|}{ Total $(n=366)$} \\
\hline & & No & $\%$ & No & $\%$ & No & $\%$ & No & $\%$ & No & $\%$ & No & $\%$ \\
\hline 1 & 0 & 29 & 37.5 & 50 & 60.0 & 34 & 52.5 & 32 & 45.0 & 16 & 22.5 & 161 & 43.5 \\
\hline 2 & $1-20$ & 8 & 10.0 & 12 & 15.0 & 15 & 22.5 & 7 & 10.0 & 14 & 20.0 & 56 & 15.5 \\
\hline 3 & $21-40$ & 20 & 25.0 & 8 & 10.0 & 5 & 7.5 & 16 & 22.5 & 18 & 25.0 & 66 & 18 \\
\hline 4 & $41-60$ & 12 & 15.0 & 4 & 5.0 & 3 & 5.0 & 7 & 10.0 & 9 & 12.5 & 35 & 9.5 \\
\hline 5 & $61-80$ & 3 & 5.0 & 4 & 5.0 & 1 & 2.5 & 3 & 5.0 & 4 & 5.0 & 15 & 4.5 \\
\hline 6 & $81-100$ & 6 & 7.5 & 4 & 5.0 & 7 & 10.0 & 5 & 7.5 & 11 & 15.0 & 33 & 9.0 \\
\hline
\end{tabular}

Table 5. Distribution of respondents based on repayment of loan (MFI members)

\begin{tabular}{|c|c|c|c|c|c|c|c|c|c|c|c|c|c|}
\hline \multirow[t]{2}{*}{ S.No } & \multirow[t]{2}{*}{ Category (in \%) } & \multicolumn{2}{|c|}{ Mechanized $(n=23)$} & \multicolumn{2}{|c|}{ Motorized $(n=28)$} & \multicolumn{2}{|c|}{ Traditional $(n=40)$} & \multicolumn{2}{|c|}{ Secondary $(n=38)$} & \multicolumn{2}{|c|}{ Tertiary $(n=26)$} & \multicolumn{2}{|c|}{ Total $(n=155)$} \\
\hline & & No & $\%$ & No & $\%$ & No & $\%$ & No & $\%$ & No & $\%$ & No & $\%$ \\
\hline 1 & 0 & 1 & 5.0 & 7 & 25.0 & 11 & 27.5 & 7 & 17.5 & 5 & 19.23 & 31 & 19 \\
\hline 2 & $1-20$ & 5 & 20.0 & 3 & 10.0 & 4 & 10.0 & 1 & 5.0 & 3 & 11.54 & 16 & 11 \\
\hline 3 & $21-40$ & 3 & 15.0 & 3 & 10.0 & 4 & 10.0 & 10 & 25.0 & 3 & 11.54 & 23 & 14.5 \\
\hline 4 & $41-60$ & 7 & 30.0 & 3 & 12.5 & 11 & 27.5 & 6 & 15.0 & 7 & 26.92 & 34 & 22 \\
\hline 5 & $61-80$ & 1 & 5.0 & 4 & 15.0 & 2 & 5.0 & 3 & 7.5 & 2 & 7.70 & 12 & 7.5 \\
\hline 6 & $81-100$ & 6 & 25.0 & 8 & 27.5 & 8 & 20.0 & 11 & 30.0 & 6 & 23.08 & 39 & 26 \\
\hline
\end{tabular}

Table 6. Distribution of respondents based on source of indebtedness

\begin{tabular}{llll}
\hline No & Sources & No. of respondents & $\%$ \\
\hline 1 & Banks & 204 & 30.86 \\
\hline 2 & Co-operatives & 38 & 5.75 \\
\hline 3 & Private money lenders & 200 & 30.26 \\
\hline 4 & Friends / Relatives & 4 & 0.61 \\
\hline 5 & Fish traders & 42 & 6.35 \\
\hline 6 & Boat owners & 4 & 0.61 \\
\hline 7 & Shop keepers & 4 & 0.61 \\
\hline 8 & Jewel loans & 10 & 1.51 \\
\hline 9 & Microfinance & 155 & 23.45 \\
\hline
\end{tabular}

catch. Banks levied 7 to 14 per cent interest, whereas microfinancial firms levied 7 to 16 per cent interest on the principal amount. Private moneylender levied 24 to 72 per cent interest on the principal amount and the interest repayments by the borrowers were either weekly or monthly.

\section{Appraisal on the functioning of the MFI/ Institutional / Non-Institutional credit agencies}

The appraisal on the functioning of the MFI / Institutional / Non-Institutional credit agencies was studied and presented in Table 7. As per the Garrets ranking technique, it was 
found that majority of the respondents ranked better for the following attributes with respect to MFI / SHG functioning like easy approval process, diverse areas of funding, provision of longer loans, provision of loan grace periods and easy repayment schedule, low interest rate, less stringent for default of payment, limited hidden cost and concerns and need for collateral security. By comparing the appraisal on the functioning of the MFI / Institutional / Non-Institutional credit agencies, from the above table it is evident that, the MFIs/SHGs are ranked better in functioning by the respondents followed by institutional and non-institutional credit agencies. out from the trap. Microfinance institutions/ self help groups significantly reduced the dependence of fisherfolk on private money lenders and considerably reduced the indebtedness level and increased their repayment capacity.

The results of the study are in agreement with impact assessment study of MFIs in Karnataka coastal belts (Vipinkumar and Swathilekshmi, 2012). MFls considerably assisted the fisherfolk in meeting their expenditure on purchasing of nets, repairing boats and for buying other accessories. By comparing the appraisal on the functioning of the MFIs/ institutional / non-institutional credit agencies, it

Table 7. Appraisal on the functioning of the MFI/Institutional/Non-institutional credit agencies

\begin{tabular}{|c|c|c|c|c|c|c|c|}
\hline \multirow[t]{2}{*}{ S.No } & \multirow[t]{2}{*}{ Attributes } & \multicolumn{2}{|c|}{ Institutional } & \multicolumn{2}{|c|}{ Non Institutional Credit } & \multicolumn{2}{|c|}{ Micro Finance Institution } \\
\hline & & Score & Rank & Score & Rank & Score & Rank \\
\hline 1 & Easy approval process & 54.6 & II & 40 & III & 57.0 & I \\
\hline 2 & Diverse areas of funding & 47.3 & II & 42.4 & III & 61.8 & I \\
\hline 3 & Eligibility of recipients & 63.8 & 1 & 51.0 & II & 36.2 & III \\
\hline 4 & Maximum loan amount & 44.4 & II & 57.0 & I & 42.9 & III \\
\hline 5 & Need for collateral security & 51.3 & II & 55.9 & I & 42.1 & III \\
\hline 6 & Provision of longer loans & 51.8 & II & 40.5 & III & 57.3 & I \\
\hline 7 & Provision of loan grace periods & 52.9 & ॥ & 41.4 & III & 56.5 & I \\
\hline 8 & Easy repayment schedule & 51.9 & II & 39.7 & III & 55.6 & I \\
\hline 9 & Low interest rate & 57.7 & I & 40.4 & III & 47.6 & ॥ \\
\hline 10 & Stringent for default of payment & 44.9 & ॥ & 59.7 & I & 43.9 & III \\
\hline 11 & Hidden cost and concerns & 50.5 & II & 59.0 & 1 & 40.4 & III \\
\hline
\end{tabular}

Finance plays a crucial role in accelerating any business activity/ economic development and fisheries sector is not an exception. The present study makes an attempt on the assessment of the extent of indebtedness among marine fisherfolk in mechanized, motorized and traditional sectors and the perceived impact assessment of MFI on coastal rural indebtedness based on the data collected from three districts in the potential coastal belts of Tamil Nadu and in general, it could be observed that the level of indebtedness in MFIs is less compared to non MFIs. Per household indebtedness in Tamil Nadu is approximately 1.03 lakhs and level of indebtedness is $87 \%$. Though the banks are the major sources of loans, private money lenders also hold good in providing loans. SHG-bank linkage had a pivotal role in successful entrepreneur capacity building of fisherfolk. Tripathi and Sharma (2007) conducted an impact assessment of SHG-Bank linkage programme on financial behaviour of rural poor in Raebareli district in Uttar Pradesh to address the issue of sustainable development of the rural poor through SHGBank linkage using participatory approach. The present study also revealed that fishermen are most often trapped under debt to private money lenders and they are not able to come is evident that the MFIs/SHGs are ranked better in functioning by the respondents followed by institutional and noninstitutional credit agencies. Non-institutional credit agencies still hold good across the sectors and Non Performing Assets (NPAs) creation existed to a great extent as loans are being used for non-fisheries activities like asset creation and social obligations. Vasantha and Manohar (2008) reported that microfinance programmes are presently being promoted as an important strategy for concurrently addressing both poverty alleviation and women's empowerment and micro financial firms must maintain efficiency levels to increase their scale of operations which surely will bring down the cost of financing and ultimately the benefits will be transferred to the poor people in terms of improving the standard of living and reasonable cost of borrowing. Another important inference which could be drawn from the study is that, as the repayment percentage of MFIs in the traditional sector was not up to the mark, there is an extreme necessity of strengthening the MFIs in the traditional sector because $93 \%$ of the fisherfolk households come under the category of traditional sector in Tamil Nadu. Therefore, concerted efforts in this direction to 
strengthen SHGs in the traditional sector are inevitable for better entrepreneurial capacity building through mobilized microfinance ventures.

\section{Acknowledgements}

The authors are grateful to Dr.G.Syda Rao, Director, CMFRI and Dr.R.Sathiadhas, the Former Head and Dr R..Narayanakumar, the present Head of the Socio Economic Evaluation \& Technology Transfer Division (SEETTD), of CMFRI for the wholehearted cooperation rendered to undertake the study.

\section{References}

CED. 2008. Agricultural Credit and its Effects on Small Farmer Indebtedness, Centre for Education and Documentation Mumbai, India, p 1-4.

CMFRI. 2010. Marine Fisheries Census 2010, Part 1, India, Govt.of India, Ministry of Agriculture, Dept. of Animal Husbandry, Dairying \& Fisheries and Central Marine Fisheries Research Institute, Indian Council of Agricultural Research, New Delhi. $p$ 1-4.

CMFRI. 2012. An Assessment of Literacy, Income and Health Status of Fishers in India, Final Report (Unpubl.), Central Marine Fisheries Research Institute, Kochi, $\mathrm{p}$ 386-392.

Garret, H. E. and R. S.Woodworth. 1969. Statistics in Psychology and Education, Vakils, Feffer and Simons Pvt. Ltd., Bombay. 329p.

Jayaraman, R. 2005. Performance Analysis of Fisherwomen Self Help Groups, Department of Fisheries Resources \& Economics, Fisheries College and Research Institute, Tamil Nadu Veterinary and Animal Sciences University, Thoothukkudi, Final Report submitted to National Bank for Agricultural and Rural Development. 63p.
Kudumbasree, 2010. Kudumbasree at a glance, In News Letter of Kudumbasree, the Govt. of Kerala initiative for microcredit, entrepreneurship and empowerment. $p$ $1-4$.

Mammoo. 2004. Income, Indebtedness and Savings among fisherfolk of Orissa, India, BOBP, Food and Agricultural Organization, United Nations\& Swedish International Development Authority. p 1-26.

Ministry of Finance. 2007. Report of the Expert Group on Agricultural Indebtedness, Department of Economic Affairs, Ministry of Finance, Government of India, $124 \mathrm{p}$.

Njie, M. and H. Mikkola. 2001. Fisheries co-management case study from the Gambia, NAGA- ICLARM, Vol 24 (3 \& 4), p 40.

NSSO. 2003. Land \& Livestock holdings and Debt \& Investment, National Sample Survey Organisation, Ministry of Statistics and Programme Implementation. Government of India. p 1-12.

Panikkar, K. K. P. 1980. Coastal rural indebtedness- A case study. Mar. Fish. Inf. Serv. T \& E Ser., 18: 8-12.

Sathiadhas, R. 2009. Inter-sectoral disparity and marginalization in marine fisheries in India. Asian Fish. Sci., 22:773-786.

Tripathi, C. K. and K. C.Sharma. 2007. Impact of SHG-Bank Linkage Programme on financial behaviour of rural poor-evidence from Raebareli district in Uttar Pradesh, Ind. J. Agri. Econ. 62(3): 296-310.

Vasantha, S. and H. L.Manohar. 2008. Challenges and opportunities of micro-finance for poor women's empowerment, Int. J. South Asian Studies, 1(2) 296-310.

Vipinkumar, V. P. 2007. Dynamics of women's self help groups in Malabar fisheries sector: A case study, Abstract, In Fisheries and Aquaculture: Strategic outlook for Asia, Book of Abstracts of 8th Asian Fisheries Forum, Kochi, organised by AFSIB Nov.20-23. p 13.

Vipinkumar, V. P. and P. S. Swathilekshmi. 2012. A study on impact of microfinance institutions on the coastal indebtedness in marine fisheries sector of Karnataka. Global J. of Biol. Agri. \& Health Sciences. 1(2) 18-27.

Vipinkumar,V. P., Shyam.S.Salim, R. Narayanakumar, R. Sathiadhas, M. S. Madan, C. Ramachandran, P. S. Swathilekshmi and B. Johnson. 2013. Coastal Rural Indebtedness and Impact of Microfinance in Marine Fisheries Sector. Central Marine Fisheries Research Institute, Kochi (e book). 165p.

Yunus Muhammed.1999. Banker to the poor: micro lending and battle against world poverty, Pacific Affairs, New York. 121p. 